\title{
Utilisation of 2,2DCP by Staphyloccocus aureus ZT and In Silico Analysis of Putative Dehalogenase
}

\author{
Zatty Zawani Zaidi*, Fahrul Huyop \\ Department of Biosciences, Faculty of Science, Universiti Teknologi Malaysia, Malaysia \\ *Corresponding Author: zattyzaza@yahoo.com
}

Submitted: 2020-09-23. Revised: 2020-11-15. Accepted: 2021-02-21

\begin{abstract}
Halogenated compound such as 2,2-dichloropropionic acid is known for its toxicity and polluted many areas especially with agricultural activities. This study focused on the isolation and characterization of the bacterium that can utilise 2,2-dichloropropionic acid from palm oil plantation in Lenga, Johor and in silico analysis of putative dehalogenase obtained from NCBI database of the same genus and species. The bacterium was isolated using an enrichment culture media supplemented with $20 \mathrm{mM}$ 2,2-dicholoropropionic acid as a carbon source. The cells were grown at $30^{\circ} \mathrm{C}$ with cells doubling time of $2.00 \pm 0.005$ hours with the maximum growth at A680nm of 1.047 overnight. The partial biochemical tests and morphological examination concluded that the bacterium belongs to the genus Staphylococcus sp.. This is the first reported studies of Staphylococcus sp. with the ability to grow on 2,2-dichloropropionic acid. The genomic DNA from NCBI database of the same species was analysed assuming the same genus and has identical genomic sequence. The full genome of Staphylococcus sp. was screened for dehalogenase gene and haloacid dehalogenase gene was detected in the mobile genetic element of the species revealed that the dehalogenase sequence has little identities to the previously reported dehalogenases. The main outcome of the studies suggesting an in situ bioremediation can be regarded as a natural process to detoxify the contaminated sites provided that the microorganisms contained a specialised gene sequence within its genome that served the nature for many long years. Whether microorganisms will be successful in destroying man-made contaminants entirely rely on what types of organisms play a role in in situ bioremediation and which contaminants are most susceptible to bioremediation.
\end{abstract}

Key words: 2,2-dichloropropionic acid;, palm oil; soil bacteria; Staphylococcus sp.; NCBI

How to Cite: Zaidi, Z. Z., \& Huyop, F. (2021). Utilisation of 2,2DCP by Staphyloccocus aureus ZT and In Silico Analysis of Putative Dehalogenase. Biosaintifika: Journal of Biology \& Biology Education, 13(1), 1-8.

DOI: http://dx.doi.org/10.15294/biosaintifika.v13i1.26322

\section{INTRODUCTION}

Xenobiotics are foreign to the environment and the diverse application of xenobiotic compound makes it very challenging to degrade by many microorganisms. The biological treatment provides a natural system to treat these toxic chemicals (Daugulis, 2001). A few solutions have been expressed using chemical techniques to treat waste, however the problem remains unsolved either expensive or ineffective in the long term and therefore the preferred way to achieve effective bioremediation is to stimulate microorganisms with nutrients and other chemicals that will enable them to destroy the contaminants at the same time. A common bioremediation system is to rely on microorganisms native to the contaminated sites.

Encouraging them to utilise these toxic chemicals at optimum levels, essential for their metabolism (Atashgahi et al., 2018). The halogenated compound is one example of synthetically made to be used in various applications. For instance these halogenated compound can be used as pesticides to maximize the crop yield and to protect the plants from diseases and pests. Herbicides are known to eliminate targeted weeds that disturbs the growth of the crop that leads to the reduction of crop yield ( $\mathrm{Au}, 2003)$. One of the herbicides manufactured was Dalapon, 2,2dichloropropionic acid (2,2-DCP) that has been used to fight against weeds such as quack grass and cattails. The 2,2-dichloropropionic acid (2,2-DCP) consists of three-carbon chain with 2 chloride ions attached to the $\alpha$-carbon (Figure 1).<smiles></smiles>

Figure 1. The common structure of 2,2dichloropropionic acid showing $\alpha$-carbon and $\beta$ carbon that allows halides to attach (Abel et al., 2012).

The presence of 2,2-DCP in the environment can lead to the soil and water pollution and the long term exposure to the chemical can cause an acute side effects (Aparecida et al., 2013). The polluted area by 2,2-DCP transpired when the particle of the 2,2-DCP does not get adsorb within the soil particle that leads to leaching (Holstun and Loomis, 1956). When the herbicide enters the water system, the pollution occurs. 
A bacteria has been used to treat 2,2-DCP in soil and this bacteria has been used as the detoxifying agent (Janssen et al., 2005). The bacteria that can degrade halogenated compound possess an enzyme called dehalogenases. The halogenated compound is degraded by a process called dehalogenation. Dehalogenation can happen enzymatically, with the usage of an enzyme to cleave the carbon-halogen bond or by a spontaneous chemical dehalogenation of unstable intermediates (Fetzner \& Lingens, 1994). The dehalogenases can be classified into a few categories according to the dehalogenation mechanisms and substrate stereospecificity (Hamid et al., 2011).

The grouping of dehalogenase include Group 1 (stereospecific) and Group 2 (non-stereospecific). Group 1 dehalogenase incudes class 1D and class $2 \mathrm{~L}$, whereas Group 2 dehalogenase consist of class $2 \mathrm{R}$ only (Harisna et al., 2017). The degradation of 2,2DCP is carried out through hydrolytic dehalogenation, where the halogen-carbon bond is cleaved by dehalogenase and the chloride ion is replaced by nucleophilic substitution with hydroxyl group derived from water (Ismail et al., 2017). Mechanisms for hydrolytic dehalogenation of 2haloalkanoic acids was proposed earlier by (Kurihara and Esaki, 2008)

The aims of the present study were to isolate a bacterium that can degrade 2,2-DCP from soil and further characterize its dehalogenase. The analysed dehalogenase gene sequence must be from the same genus and species that was previously isolated. The benefit of the genomic screening of dehalogenases in the database may shed a light that the dehalogenase producing organism are common to a certain microorganisms and important on the aspect of bioremediation.

\section{METHODS}

\section{Growth media preparation}

The bacterium was grown in a minimal medium supplemented with 2,2-DCP as carbon source. The stock solution was prepared by mixing $10 \mathrm{x}$ of basal salts containing $\mathrm{K}_{2} \mathrm{HPO}_{4}(16.22 \mathrm{~g}), \mathrm{NaH}_{2} \mathrm{PO}_{4} \cdot 2 \mathrm{H}_{2} \mathrm{O}$ $(5.00 \mathrm{~g})$ and $\left(\mathrm{NH}_{4}\right) 2 \mathrm{SO}_{4}(12.50 \mathrm{~g})$ with metal salts containing Nitriloacetic Acid $(0.5 \mathrm{~g})$, $\mathrm{MgSO}_{4} .7 \mathrm{H}_{2} \mathrm{O}(1.00 \mathrm{~g}), \quad \mathrm{Fe}_{2} \mathrm{SO}_{4} .7 \mathrm{H}_{2} \mathrm{O} \quad(0.06 \mathrm{~g})$, $\mathrm{MnSO}_{4} \cdot \mathrm{H}_{2} \mathrm{O} \quad(0.015 \mathrm{~g}), \quad \mathrm{ZnSO}_{4} \cdot \mathrm{H}_{2} \mathrm{O} \quad(0.015 \mathrm{~g})$, $\mathrm{CoCl}_{2} \cdot 6 \mathrm{H}_{2} \mathrm{O}(0.005 \mathrm{~g})$ in distilled water (Wong and Huyop, 2011). Minimal media for the bacterial growth contained $10 \mathrm{ml}$ of trace metal and $10 \mathrm{ml}$ of basal salts per $100 \mathrm{ml}$ of distilled water and were autoclaved at $121^{\circ} \mathrm{C}$ for 15 minutes at $15 \mathrm{psi}$. The carbon sources ( $1 \mathrm{M}$ of 2,2-DCP and $1 \mathrm{M}$ of pyruvate) were sterilized separately and added aseptically to the media to the desired final concentration (Almaki et al., 2016). To prepare solid minimal media, Oxoid bacteriological agar (1.5\% w/v) was added prior to sterilization. Samples were removed periodically and optical density reading was taken every two hours for 20 hours period at the absorbance of A680nm.

\section{Sample preparation}

Soil sample (5 g) from palm oil plantation from Lenga, Johor was mixed in minimal medium containing $10 \mathrm{mM}$ of 2,2-DCP and incubated in the rotary shaker at $30^{\circ} \mathrm{C}$. Bacterial growth was monitored every two hours. For the isolation of pure colonies, $0.1 \mathrm{~mL}$ of aliquot was spread onto solid minimal media contained $20 \mathrm{mM}$ 2,2-DCP. For cells purification, colonies were selected and subcultured onto fresh plates containing $10 \mathrm{mM}$ of 2,2-DCP as carbon source. Plates were incubated at $30^{\circ} \mathrm{C}$ until colonies were formed.

\section{Biochemical tests}

A variety of biochemical tests that were carried out including starch hydrolysis tests, oxidase test, catalase test, lactose utilization test, Simmons citrate test, indole test, and urease test to characterize bacteria's biochemical properties. All test media were incubated at a temperature ranging from 30 to $35^{\circ} \mathrm{C}$ separately to observe their optimum bacterial activity.

\section{Genome analysis}

Amino acid sequence of haloacid dehalogenase from Staphylococcus sp. was acquired from the National Center of Biotechnology Information (NCBI) (https://www.ncbi.nlm.nih.gov/). The sequence was derived from the plasmid of Staphylococcus aureus strain ST398 with Genbank accession number CEO92199.1. The sequence contained 133 amino acids in total. The sequence of the amino acid is presented in Figure 2.

\section{Amino acid sequence alignment}

Six sequences of established dehalogenases were obtained from NCBI and compared to the haloacid dehalogenase from Staphylococcus aureus strain ST398 (Figure 2). Multiple sequence alignment and pairwise comparison were carried out to determine the specific location of conserved region of each amino acid.

\section{RESULTS AND DISCUSSION}

\section{Isolation of 2,2-DCP degrading bacterium}

The growth of mix culture was seen on minimal media agar plate with $10 \mathrm{mM}$ 2,2-DCP as a carbon source. The incubation period was monitored over 10 
days at $30^{\circ} \mathrm{C}$ (Figure $\left.3 \mathrm{~A}\right)$. To accelerate the growth of all colonies, $0.05 \%$ yeast extract was added as a supplement in the minimal media. Then, a single colony was isolated by repeatedly streaking onto a fresh plates on the same media preparation. Finally, a single colony was selected for further studies (Figure 3B). A single isolate was named as strain ZT.

\section{MKERNIQNED YTVCAKNLVS AYEGAPWYNK WTEKEALLRV EATMSGFNSK GYVIEENNKV 60 \\ 61 IAMCIGRIDY YFSGMNQFCI DEFHVIPEFQ KNGVGKKLMN SVSNSLKLDE IYKIFLITGG 120 \\ 121 ELAENFKKKK TAS* 133}

Figure 2. The full amino acid sequence of haloacid dehalogenase from the plasmid of Staphylococcus aureus strain ST398 (accession number of CEO92199.1)

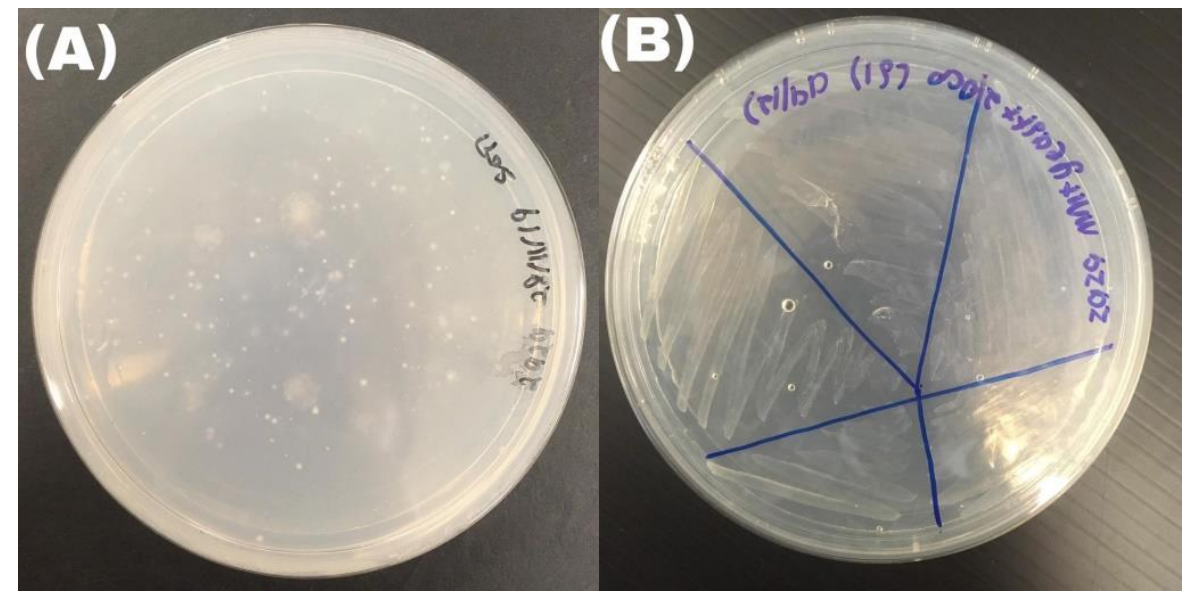

Figure 3. (A) A mix culture from soil were grown on $10 \mathrm{mM}$ 2,2-DCP minimal medium over 10 days period. From this step, a single colony was selected and streaked onto a fresh plate containing the same media component. (B) A selected colony was grown on the same media component with $10 \mathrm{mM}$ of 2,2-DCP and $0.05 \%$ yeast after 48 hours of incubation period at $30^{\circ} \mathrm{C}$.

\section{Morphological analysis of strain ZT on solid agar medium}

Strain ZT was subjected to basic morphological tests as summarised in Table 1. It was also grown on the minimal media agar with different concentrations of 2,2-DCP to determine the optimum growth condition. Some colonies started to form at $10 \mathrm{mM}$ and $20 \mathrm{mM}$ plates while no single growth seen at 30 $\mathrm{mM}$ and $40 \mathrm{mM}$ of 2,2-DCP plates. This suggests at 30 and $40 \mathrm{mM}$ 2,2-DCP was toxic to the cells. The basic morphological analyses of the colonies are summarised in Table 1.

Table 1. The basic morphological characteristics of strain ZT on the minimal media with $10 \mathrm{mM} \mathrm{2,2-}$ DCP incubated for over 24 hours at $30^{\circ} \mathrm{C}$

\begin{tabular}{ll}
\hline Parameters & Results \\
\hline Margin & Entire \\
Pigmentation & Yellowish \\
Texture & Mucoid \\
Shape & Round \\
\hline
\end{tabular}

\section{Analysis of growth in liquid 2,2-DCP minimal medium}

The growth profile was analyzed by inoculating strain ZT into minimal liquid media with different concentrations of 2,2 DCP $(10 \mathrm{mM}, 20 \mathrm{mM}, 30 \mathrm{mM}$, and $40 \mathrm{mM}$ ). The growth profiles were measured at A680nm at every two hours interval for over 20 hours. The growth profiles are shown in Figure 4.

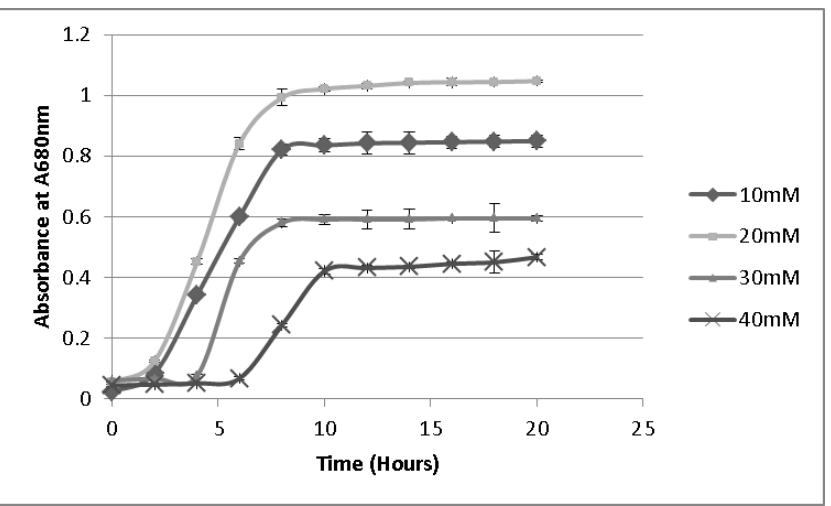

Figure 4. Growth analysis of strain $\mathrm{ZT}$ at $10 \mathrm{mM}, 20$ $\mathrm{mM}, 30 \mathrm{mM}$, and $40 \mathrm{mM}$ of 2,2-DCP incubated at $30^{\circ} \mathrm{C}$. Reading were taken in triplicates \pm standard deviation.

The growth rates and doubling times of each concentration was observed and calculated. At 20 $\mathrm{mM} 2,2-\mathrm{DCP}$ showed the best growth condition. The maximum growth was achieved at A680nm of 1.047 
with calculated cells doubling time of 2 hours. Meanwhile, growth at $40 \mathrm{mM}$ of 2,2-DCP was the least favourable, as it grows to only 0.467 with unpremeditated doubling time as the cells were presumably dead after 10 hours incubation period. Table 2 summarised the maximum growth of strain $\mathrm{ZT}$ in each 2,2-DCP concentration.

Table 2. The maximum growth and calculated cells doubling time of strain ZT in each 2,2-DCP concentration.

\begin{tabular}{lll}
\hline Concentration & $\begin{array}{l}\text { Maximum } \\
\text { growth }\end{array}$ & Doubling time \\
\hline $10 \mathrm{mM}$ & 0.849 & $1.824 \pm 0.002$ \\
$20 \mathrm{mM}$ & 1.047 & $2 \pm 0.005$ \\
$30 \mathrm{mM}$ & 0.595 & $1.355 \pm 0.009$ \\
$40 \mathrm{mM}$ & 0.467 & NG \\
\hline
\end{tabular}

Strain ZT showed good growth condition at 10 $\mathrm{mM}, 20 \mathrm{mM}$ and $30 \mathrm{mM}$ of 2,2-DCP, whereas another study showed that Acinetobacter calcoaceticus strain BB9.2 and Pseudomonas plecoglossicida strain BC14.3 could grow well in the media containing up to $50 \mathrm{mM}$ and $80 \mathrm{mM}$ of 2,2DCP (Mulyawati et al., 2018). Most of the previously reported cases showed that 2,2-DCP above $30 \mathrm{mM}$ was toxic to the cells (Oyewusi et al., 2020, Ismail et al., 2017, Edbeib et al., 2017, Muslem et al., 2017, Heidarrezaei et al., 2020). This can be concluded that different bacteria have different mechanisms of uptake of 2,2-DCP and the $\mathrm{km}$ values or the affinity of the dehalogenase enzyme. However, E. coli could not grow on 2,2-DCP, and this can be attributed to the poor uptake system and/or no expression of the dehalogenase gene in the cells (Jing, et al., 2010).

The dehalogenation product of 2,2-DCP was pyruvate. Therefore, ZT strain was tested to grow in minimal medium containing $10 \mathrm{mM}$ pyruvate as a carbon source. Figure 5 shows ZT strain grew well in pyruvate with cells doubling time of 2.89 hours with a maximum growth of 0.694 , whereas the doubling time of strain ZT in 2,2-DCP was 2.85 hours with a maximum growth of 0.624 . Likewise, Rhizobium $\mathrm{sp}$. $\mathrm{RC} 1$ could grow well in 2,2-DCP but not in monochloroacetate (MCA). This attributed to the lacking of an uptake system of MCA into the cells and the product of MCA degradation like glycolate is not a substrate for growth (Huyop and Cooper, 2003).

\section{Identification of ZT strain by biochemical tests}

Gram staining was carried out and strain ZT was Gram-positive cocci in clusters (Figure 6). Full results of basic biochemical tests is shown in Table 3 . Using the Bergey's manual of systematic bacteriology, it was proposed that strain ZT belongs to the genus Staphylococcus sp..

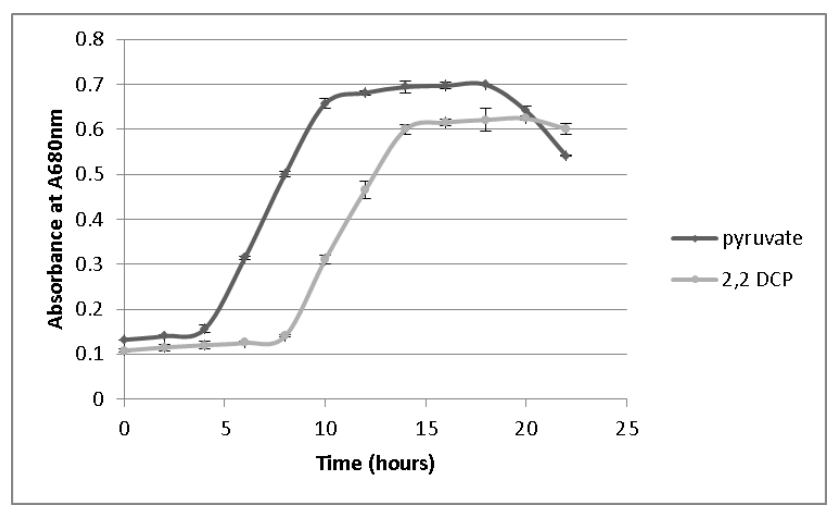

Figure 5. The growth profile of strain ZT in $10 \mathrm{mM}$ liquid minimal media supplemented with pyruvate and $20 \mathrm{mM}$ of 2,2-DCP, at $30^{\circ} \mathrm{C}$. Reading were taken in triplicates \pm standard deviation

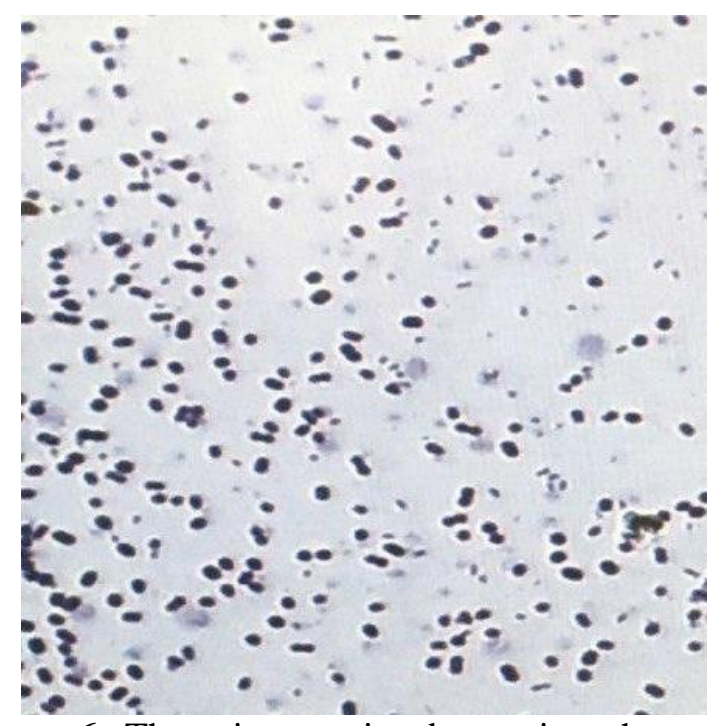

Figure 6. The microscopic observation shows that strain ZT is Gram-positive cocci. (Magnification of 1000x)

Table 3. Basic biochemical tests of strain ZT compared to the biochemical test results obtained from the previous study

\begin{tabular}{lll}
\hline Biochemical tests & Results & $\begin{array}{l}\text { References (Aggarwal } \\
\text { et al., 2012) }\end{array}$ \\
\hline Starch test & - & - \\
$\begin{array}{l}\text { Indole test } \\
\text { Oxidase test }\end{array}$ & - & - \\
Catalase test & + & - \\
Citrate test & + & + \\
$\begin{array}{l}\text { Lactose } \\
\text { fermentation test }\end{array}$ & - & + \\
Urease test & + & + \\
\hline
\end{tabular}

$(+)$ indicates positive, (-) indicates negative

Currently, this is the first reported species that can degrade 2,2-DCP. However, according to Camboim et al. (2012), Staphylococcus spp. strain ECPB04 can degrade sodium fluoroacetate, which another type of halogenated compound. Another study conducted 
revealed that Staphylococcus xylosus can degrade 1,2-dichlorobenzene in the presence of glucose (Ziagova and Liakopoulou-Kyriakides, 2007).

\section{Computational analysis}

Since Staphylococcus sp. ZT strain could grow on 2,2-DCP minimal medium, it was hypothesized that strain ZT possesses dehalogenase enzyme. Therefore, the genome from the gene bank of the same genus of the isolated bacteria was investigated for the presence of putative dehalogenase protein. The amino acid sequence was acquired from the National Center for Biotechnology Information (NCBI) (https://www.ncbi.nlm.nih.gov/). The sequence was haloacid dehalogenase from the plasmid of Staphylococcus aureus strain ST398 (Genbank accession number CEO92199.1; (Fessler et al., 2011). The putative dehalogenase amino acid sequence from strain ST398 was then compared to the common established dehalogenase amino acid sequence obtained from the database to determine the similarities of each haloacid dehalogenases.

\section{The amino acid sequence comparison}

The dehalogenase amino acid sequence from different species were selected to be compared with the sequence from the Staphylococcus aureus strain ST398 (Table 4). Dehalogenase from strain ST398 was designated as DehST398 (current study).

Table 4. The list of dehalogenases used in comparison with the haloacid dehalogenase from Staphylococcus aureus strain ST398 (Genbank accession number: CEO92199.1)

\begin{tabular}{|c|c|c|c|c|}
\hline Bacteria & $\begin{array}{l}\text { Dehalogenase } \\
\text { type }\end{array}$ & $\begin{array}{l}\text { Accession } \\
\text { number }\end{array}$ & $\begin{array}{l}\text { Sequence } \\
\text { length }\end{array}$ & References \\
\hline Klebsiella pneumoniae & $\mathrm{Had}$ & ODM40643.1 & 229 & (Zhou et al.) \\
\hline Rhizobium sp. RC1 & DehL & CAA63794 & 279 & (Cairns et al., 1996) \\
\hline $\begin{array}{l}\text { Pseudomonas putida strain } \\
\text { AJ1 }\end{array}$ & HadL & AAA25832 & 227 & Barth et al., (1992) \\
\hline $\begin{array}{l}\text { Pseudomonas putida strain } \\
109\end{array}$ & DehH109 & BAA04474 & 224 & $\begin{array}{l}\text { (Kawasaki et al., } \\
\text { 1994) }\end{array}$ \\
\hline $\begin{array}{l}\text { Xanthobacter autotrophicus } \\
\text { strain GJ10 }\end{array}$ & DhlB & AAA27590 & 253 & $\begin{array}{l}\text { (Van Der Ploeg et al., } \\
\text { 1991) }\end{array}$ \\
\hline Pseudomonas sp CBS3 & DehCI & AAA63640.1 & 227 & $\begin{array}{l}\text { (Schneider et al., } \\
\text { 1991) }\end{array}$ \\
\hline
\end{tabular}

\section{Pairwise sequence alignment}

The pairwise comparison was carried out to determine the identities of each dehalogenase against DehST398. The results are presented in Table 5. The sequence identity were less than $10 \%$ and somewhat different to each other suggesting DehST398 might serve different functions as the reported amino acid sequences.

\section{Multiple Sequence Alignment}

The multiple sequence alignment was carried out for all six amino acid sequences using common MultiAlin version 5.4.1 software (Corpet, 1988). The multiple sequence alignment was carried out to determine the similarities of the location of the conservative region and the arrangement of the sequence. The alignment has a minimum sequence length of 133 and the maximum length of the sequence of 279 with an average sequence length of
224. Figure 7 showed a single conserved region at Arg207 (R207).

Table 5. The pairwise comparison between DehST398 of haloacid dehalogenase Staphylococcus aureus strain ST398 with six different haloacid dehalogenases from other species. The identity of each enzyme was less than $10 \%$.

\begin{tabular}{clc}
\hline \multicolumn{2}{c}{ Pairwise } & Identity (\%) \\
\hline & Had & 0.9 \\
& DehL & 2.6 \\
DehST398 & HadL & 5.3 \\
& DehH109 & 6.1 \\
& DhlB & 2.9 \\
& DehCI & 2.4 \\
\hline
\end{tabular}


DehST398

Deh 1

Deh2

Deh3

Deh 4

Deh 6

Deh5

Consensus

DehST398

Deh1

Deh2

Deh3

Deh 4

Deh 6

Deh5

Consensus

DehST398

Deh 1

Deh2

Deh 3

Deh 4

Deh 6

Deh5

Consensus

DehST398

Deh 1

Deh2

Deh 3

Deh4

Deh 6

Deh5

Consensus

DehST398

Deh 1

Deh2

Deh3

Deh 4

Deh 6

Deh5

Consensus

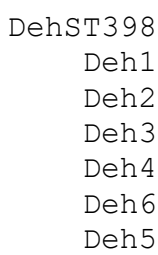

Deh2

Deh 3

Deh 4

Deh6

Deh5

Consensus

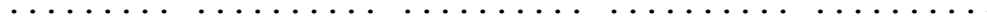
MIRAIVTDIE GTTSDIR.FV HNVLFPYARE RLAGFVTAQQ HAEPVKTILD ..MSLKKRIK ALTFDTGGTV ARLAVPASEM LLRRQAAGTE SIETGRYWPM .....MKNIQ GIVFDLYGTL YDV.....HSV VQACEEVYPG QGDAISRLWR .....MQPIE GIVFDLYGTL YDV....HSV VQACESAYPG QGEAISRLWR .....MDPIR ACVEDAYGTL LDV.....NTA VMKHAHDIGG CAEELSSLWR ......MIK AVVFDAYGTL FDV....QSV ADATERAYPG RGEYITQVWR

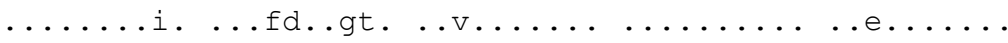

51

100 . NLRRETDAPA ASTADLITTL FAFMDEDRKS T.ALKALQGI IWRDGYLNGD NCRRRSMQAM LNLGREPPRH TTLMVRHQFS LDAILAEEGL DVFDDEDRAH QKQLEYTWLR SLMGRYVNFE KATEDALRFT CTHLGLSLDD ETHQRLSDAY QKQLEYTWLS SLMGRYASFE QRTEEALRYT CKHLGLATDE TTLRQLGQAY QRQLEYSWTR TLMGRYADFW QLTTEALDFA LESFGLLERT DLKNRLLDAY QKQLEYSWLR ALMGRYADFW GVTREALAYT LGTLGLEPDE SFLAGMAQAY

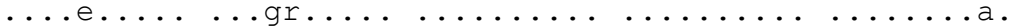

101 $\ldots \ldots \ldots \ldots \ldots \ldots \ldots \ldots \ldots \ldots \ldots \ldots \ldots \ldots \ldots \ldots$ MKFRIQNED FTGHLYPDVL PALEKWKAQG IDLYVYSSGS VAAQKLLFGY SDE.GDITHL CWDAPHSFDP GDVRDGLARL RDRYIAVSFT FVSHRLIIDT TSVVTGLMWM LHLTPYADTA DAVRRLKAAG LPLGIISNGS HCSIEQVVTN SEMNWAFDQL LHLAPHPDTT AALRRLKASG LPMAIASNGS HHSIEQVVSH SDMGWAFDHL HELSAYPDAV GTLGALKAAG FTTAILSNGN NEMLRGALRA GNLTEALDQC NRLTPYPDAA QCLAEL..AP LKRAILSNGA PDMLQALVAN AGLTDSFDAV ....урd...............s.g. .............

151

200

YTVCAKNLVS AYEGAPWYNK WTEKEALLRV EATMSGFNSK GYVIEENNKV FTGYFDTLVG AKREVQSYRN IAEHLGHAPG TILELSDIHQ ELDAAEAAGL RSCLVREWVS TSHCQQICES GGYASRKALR NALWSHAIVS ILMQRETSAS IS..VEDVQV FKPDSRVYSL AEKRMGFPKE NILFVSSNAW DASAASNFGF IS..VETVKV FKPDNRVYSL AEQTMAIPRD RLLFVSSNSW DATGARHFGE IS..VDEIKI YKPDPRVYQF ACDRLDVRPS EVCFVSSNAW DIGGAGAFGF IS..VDAKRV FKPHPDSYAL VEEVLGVTPA EVLFVSSNGF DVGGAKNFGF .s....v. .k....y. ..e.......lf.s.n. ...ae..g.

201

250

IAMCIGRIDY YFSGMNQFCI DEFHVIPEFQ KNGVGKKLMN SVSNSLKLDE

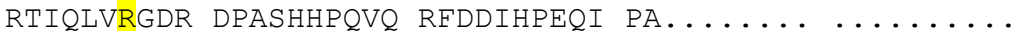
GQPLINRPDE WGKAIGPQKP P.PGSEPYDI ELNSFLELAA FLESESSLKA PVCWINRQNG AFDELDAKPT HVVRNLAEMS NWLVNSLD......... PVCWVNRQGA VFDELGATPT REVRDLGEMS DWLLD........... NTVRINRINK PQEYSFAPQR HQLSSLSELP QLLLRLTQ.......... SVARVARLSQ .EALARELVS GTIAPLTMFK ALRMREETYA EAPDFVVPAL ...i.R.d

251 282

IYKIFLITGG ELAENFKKKK TAS....... $\ldots \ldots \ldots \ldots \ldots \ldots \ldots \ldots \ldots$ NAISGAVRGS AARPTAPGRY ALVALYASAE GK $\ldots \ldots \ldots \ldots \ldots \ldots \ldots \ldots \ldots \ldots \ldots \ldots \ldots \ldots \ldots \ldots$ $\ldots \ldots \ldots \ldots+\cdots \cdots \cdots \cdots+\cdots$

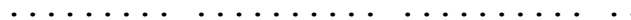
GDLPRLVRGM AGAHLAPAV. $\ldots \ldots \ldots \ldots \ldots$ $\ldots \ldots \ldots, \ldots \ldots \ldots \ldots \ldots \ldots \ldots$

Figure 7. The multiple sequence alignment of haloacid dehalogenase from Staphylococcus aureus (CEO92199.1) (Feßler et al., 2011), Klebsiella pneumoniae (ODM40643.1) (Zhou et al.), Rhizobium sp. RC1(CAA63794) (Cairns et al., 1996), Pseudomonas putida strain AJ1(AAA25832) (Cairns et al., 1996), Pseudomonas putida strain 109 (BAA04474) (Kawasaki et al., 1994), Xanthobacter autotrophicus strain GJ10 (AAA27590) (Van Der Ploeg et al., 1991), and Pseudomonas sp. CBS3 (AAA63640.1) (Schneider et al., 1991) 
This is the first reported study on Staphylococcus sp. with the ability to grow on 2,2dichloropropionic acid a model substrate for pollutant degradation. The genomic DNA from the NCBI database of similar bacterial species was analyzed, assuming that the same genus and species have identical genomic sequence. Screening the full genome of Staphylococcus sp. for the dehalogenase gene detected the gene in the species' mobile genetic element. The dehalogenase sequence showed low identity to other previously reported dehalogenases.

\section{CONCLUSION}

The current study offers new perspectives on the research aside from bioprospecting for new microorganisms. It is also vital that the genomic analysis focuses on the same isolated species when screening potential enzymes and proteins. This study may shed light on the biochemical characteristics of dehalogenases isolated from the bacterial plasmid, with possible bioremediation use. This study isolated the bacterium from an oil palm plantation and identified as Staphylococcus sp., which has yet to be reported.

Hence, further investigation into the protein and its 3D structure is necessary to identify the bacteria's conserved region. This study's findings further add to the list of bacteria capable of degrading halogenated compounds, particularly the 2,2-dichloropropionic acid.

\section{ACKNOWLEDGEMENT}

We are grateful to the Fundamental Research Grant Scheme (FRGS) R.J130000.7854.5F189 (Ministry of Higher Education Malaysia) and RUGUTM-HR-Q.J130000.2414.08G59 (University Teknologi Malaysia) for partial financial assistance for research materials.

\section{REFERENCES}

Abel, E., Ibrahim, N. \& Huyop, F. (2012). Identification of Serratia marcescens SE1 and determination of its herbicide 2, 2dichloropropionate $(2, \quad 2-\mathrm{DCP})$ degradation potential. Malaysian Journal of Microbiology, 8, 259-265.

Aggarwal, G., Tiwari, A., Dhiman, P., Arora, D., Pabbi, S. \& Setya, D. (2012). Red blood cell exchange in sickle cell disease patient with multiple alloantibodies. International Journal of Nutrition, Pharmacology, Neurological Diseases, 2, 70-73.
Almaki, J. H., Nasiri, R., Soon, W. T. \& Huyop, F. Z. (2016). Identification of novel bacterial species capable of degrading dalapon using 16s rRNA sequencing. Jurnal Teknologi, 78(6), 77-82.

Aparecida, M., Camargo, B. \& Miyuki, M. (2013). Toxicity of Herbicides: Impact on Aquatic and Soil Biota and Human Health In: Herbicides Current Research and Case Studies in Use. Ed. Andrew J. Price and Jessica A. Kelton IntechOpen Atashgahi, S., Shetty, S. A., Smidt, H. \& De Vos, W. M. (2018). Flux, Impact, and Fate of Halogenated Xenobiotic Compounds in the Gut. Frontiers in Physiology, 9.

$\mathrm{Au}$, A. M. (2003). Pesticides and Herbicides | Types, Uses, and Determination of Herbicides. In: CABALLERO, B. (ed.) Encyclopedia of Food Sciences and Nutrition (Second Edition). Oxford: Academic Press.

Cairns, S. S., Cornish, A. \& Cooper, R. A. (1996). Cloning, sequencing and expression in Escherichia coli of two Rhizobium sp. genes encoding haloalkanoate dehalogenases of opposite stereospecificity. European journal of biochemistry, 235, 744-749.

Camboim, E. K. A., Tadra-Sfeir, M. Z., De Souza, E. M., Pedrosa, F. D. O., Andrade, P. P., Mcsweeney, C. S., Riet-Correa, F. \& Melo, M. A. (2012). Defluorination of sodium fluoroacetate by bacteria from soil and plants in Brazil. TheScientificWorldJournal, 2012, 149893149893.

Corpet, F. (1988). Multiple sequence alignment with hierarchical clustering. Nucleic acids research, 16, 10881-10890.

Daugulis, A. J. (2001). Two-phase partitioning bioreactors: a new technology platform for destroying xenobiotics. TRENDS in Biotechnology, 19, 457-462.

Edbeib, M., Wahab, R. \& Huyop, F. (2017). Isolation and characterization of a novel 2, 2-DCPdegrading Achromobacter sp. $\mathrm{M} \times 2$ isolated from contaminated seawater of Desaru Beach, Southern Malaysia. Journal of Engineering and Applied Sciences, 12, 4306-4309.

Fetzner, S. \& Linges, F. (1994) Bacterial dehalogenases: biochemistry, genetics, and biotechnological applications. Microbiology Review, 58(4), 641-685.

Fessler, A. T., Kadlec, K. \& Schwarz, S. (2011). Novel apramycin resistance gene apmA in bovine and porcine methicillin-resistant Staphylococcus aureus ST398 isolates. Antimicrobial agents and chemotherapy, 55, 373-375.

Hamid, T. H. T. A., Hamid, A. A. A. \& Huyop, F. (2011). A review on non-stereospecific 
haloalkanoic acid dehalogenases. African Journal of Biotechnology, 10, 9725-9736.

Harisna, A. H., Edbeib, M. F., Adamu, A., Hamid, A. A. A., Wahab, R. A. \& Huyop, F. (2017). In silico molecular analysis of novel L-specific dehalogenase from Rhizobium sp. RC1. Malaysian Journal of Microbiology, 13(1), 50-60.

Heidarrezaei, M., Shokravi, H., Huyop, F., Rahimian Koloor, S. S. \& Petru, M. (2020). Isolation and Characterization of a Novel Bacterium from the Marine Environment for Trichloroacetic Acid Bioremediation. Applied Sciences, 10.

Holstun, J. \& Loomis, W. (1956). Leaching and decomposition of 2, 2-dichloropropionic acid in several Iowa soils. Weeds, 4, 205-217.

Huyop, F. Z. \& Cooper, R. A. (2003). A potential use of dehalogenase D (DehD) from Rhizobium sp. for industrial process. Jurnal teknologi, 39, 1-8.

Ismail, S., Wahab, R. \& Huyop, F. (2017). Microbial isolation and degradation of selected haloalkanoic aliphatic acids by locally isolated bacteria: A review. Malaysian Journal of Microbiology, 13, 261-272.

Janssen, D. B., Dinkla, I. J. T., Poelarends, G. J. \& Terpstra, P. (2005). Bacterial degradation of xenobiotic compounds: evolution and distribution of novel enzyme activities. Environmental Microbiology, 7, 1868-1882.

Jing, N.H., Wahab, Ab. R., Hamadan, S. \& Huyop, F. (2010). Cloning and DNA Sequence Analysis of the Haloalkanoic Permease Uptake Gene from Rhizobium sp. RC1. Biotechnology, 9, 319-325.

Kawasaki, H., Toyama, T., Maeda, T., Nishino, H. \& Tonomura, K. (1994). Cloning and sequence analysis of a plasmid-encoded 2-haloacid dehalogenase gene from Pseudomonas putida no. 109. Bioscience, biotechnology, and biochemistry, $58,160-163$.

Kurihara, T. \& Esaki, N. (2008). Bacterial hydrolytic dehalogenases and related enzymes: Occurrences, reaction mechanisms, and applications. The Chemical Record, 8, 67-74.
Mulyawati, A. I., Huyop, F., Adamu, A. B., Aliyu, F. \& Mustafa, I. (2018). Analysis of 2,2-DCP degrading bacteria isolated from a paddy field at a rural area in Malang, Indonesia. Malaysian Journal of Microbiology, 14(7):674-679.

Muslem, W. H., Edbeib, M., Wahab, R., Khalili, E., Zakaria, I. \& Huyop, F. (2017). The potential of a novel $\beta$-specific dehalogenase from Bacillus cereus $\mathrm{WH} 2$ as a bioremediation agent for the removal of $\beta$-haloalkanoic acids. Malaysian Journal of Microbiology, 13(4), 298-307.

Oyewusi, H., Wahab, R., Kaya, Y., Edbeib, M. \& Huyop, F. (2020). Alternative Bioremediation Agents against Haloacids, Haloacetates and Chlorpyrifos Using Novel Halogen-Degrading Bacterial Isolates from the Hypersaline Lake Tuz. Catalysts, 10, 651.

Schneider, B., Müller, R., Frank, R. \& Lingens, F. (1991). Complete nucleotide sequences and comparison of the structural genes of two 2haloalkanoic acid dehalogenases from Pseudomonas sp. strain CBS3. Journal of bacteriology, 173, 1530-1535.

Van Der Ploeg, J., Van Hall, G. \& Janssen, D. B. (1991). Characterization of the haloacid dehalogenase from Xanthobacter autotrophicus GJ10 and sequencing of the dhlB gene. Journal of bacteriology, 173, 7925-7933.

Wong, W.-Y. \& Huyop, F. (2011). Characterization of a Labrys sp. strain Wy1 able to utilize 2, 2dichloropropionate (2, 2-DCP) as sole source of carbon. African Journal of Microbiology Research, 5, 3282-3288.

Zhou, Y.-J., Zhu, S., Yang, D.-H., Zhao, D.-D., Li, J.J. \& Liu, S.-L. (2007). Characterisation of Klebsiella sp. S1: a bacterial producer of secoisolariciresinol through biotransformation. Canadian Journal of Microbiology, 63(1), 1-10

Ziagova, M. \& Liakopoulou-Kyriakides, M. (2007). Comparison of cometabolic degradation of 1,2dichlorobenzene by Pseudomonas sp. and Staphylococcus xylosus. Enzyme and Microbial Technology, 40, 1244-1250. 